\title{
PENINGKATAN KEAKTIFAN MENGEMUKAKAN PENDAPAT MELALUI BIMBINGAN PRIBADI DENGAN TEKNIK REINFORCEMENT PADA SISWA SMP NEGERI 1 TAKERAN KAB. MAGETAN
}

\author{
Yulia Rahmatika Aziza * \\ Vitalis Djarot Sumarwoto **
}

\begin{abstract}
Abstrak
Proses pembelajaran siswa di sekolah dalam beberapa aspek menuntut keaktifan siswa dalam mengemukakan pendapat. Tuntutan tersebut bertujuan untuk mengetahui seberapa besar pemahaman siswa terhadap obyek yang dihadapinya. Semakin siswa menunjukkan keaktifan dalam mengemukakan pendapat, semakin memberi petunjuk tentang seberapa besar pemahaman siswa terhadap materi yang diterimanya.

Menghadapi tuntutan di atas ternyata tidak semua siswa menunjukkan perilaku yang sama. Hasil observasi awal yang peneliti lakukan pada minggu pertama dan kedua pada bulan Mei 2013, terhadap siswa kelas VII SMP Negeri 1 Takeran Kabupaten Magetan, yang berjumlah 110 siswa diketahui terdapat 85 siswa yang tidak aktif mengemukakan pendapatnya. Penyebab utamanya adalah: dalam proses pembelajaran tidak dikondisikan untuk mengeluarkan pendapat, dan takut jika pendapatnya salah.

Kenyataan di atas perlu disikapi secara positif, yaitu dengan mencari solusi terhadap masalah tersebut, sehingga tidak menghambat perkembangan siswa. Solusi yang ditawarkan adalah dengan memberi bimbingan pribadi melalui tekhnik reinforcement. Hakikat teknik reinforcement adalah suatu tindakan penguatan didefinisikan sebagai setiap konsekuensi yang memperkuat dan meningkatkan frekuensi perilaku.

Subyek penelitian adalah 20 dari 85 siswa total siswa yang bermasalah pada keaktifan mengemukakan pendapat. Penetapan sampel dengan teknik random sampling. Kepada 20 siswa diberi treatment berupa bimbingan pribadi melalui teknik reinforcement. Frekuensi pemberian bimbingan sebanyak 4 kali pertemuan, lama bimbingan 60 menit/pertemuan, dan diakhiri dengan evaluasi. Hasil evaluasi berupa kumpulan skor dari observasi dan hasil isian angket antara sebelum dan setelah diberi treatment, kemudian dibandingkan, untuk mengetahui seberapa besar peningkatan keaktifan mengemukakan pendapat.

Analisis data menggunakan rumus t-skor. Hasil analisis data menunjukkan terdapat peningkatan yang signifikan. Simpulan yang diperoleh adalah bahwa bimbingan pribadi dengan teknik reinforcement dapat meningkatkan keaktifan mengemukakan pendapat siswa kelas VII SMP Negeri 1 Takeran Kabupaten Magetan tahun pelajaran 2013/2014.
\end{abstract}

Kata Kunci: Bimbingan pribadi dengan teknik reinforcement dan Keaktifan mengemukakan pendapat

* Yulia Rahmatika Aziza adalah Mahasiswa Program Studi Bimbingan dan Konseling Fakultas Ilmu Pendidikan IKIP PGRI Madiun.

** Vitalis Djarot Sumarwoto adalah Dosen Program Studi Bimbingan dan Konseling Fakultas Ilmu Pendidikan IKIP PGRI Madiun. 


\section{Pendahuluan}

Tidak semua siswa memiliki keaktifan dalam mengemukakan pendapat ketika di sekolah diadakan kegiatan diskusi atau kerja kelompok. Penyebabnya dapat bersifat internal maupun eksternal. Penyebab internal seperti takut salah atau malu berpendapat. Penyebab eksternal berkaitan erat dengan proses pembelajaran dengan pendekatan behavioristik, sehingga siswa cenderung mengikuti apa yang diterima dari guru/pendidik. Proses belajar-mengajar di sekolah menuntut siswa tenang, duduk manis, mendengar penjelasan guru, dan mengerjakan tugas atas dasar lembar kerja siswa. Siswa sekedar mengejar angka (nilai, ranking), bukan atas dasar pemahaman materi yang dipelajari. Semenjak ditetapkan menjadi siswa kurang diberi kesempatan untuk berbicara, menanggapi materi yang diterimanya, atau mengemukakan pendapat yang mungkin dapat saja berbeda dengan gurunya. Akibatnya pembelajaran terkesan sekedar membentuk robotrobot dari waktu ke waktu, dan terus berkesinambungan.

Berdasarkan hasil observasi dan wawancara peneliti dengan beberapa staf sekolah (guru dan wali siswa), serta dokumentasi dari konselor sekolah, pada minggu pertama dan kedua, bulan Mei 2014. Observasi dan wawancara peneliti lakukan khusus pada siswa kelas VII SMP Negeri 1 Takeran Kabupaten Magetan mengenai keaktifan mengemukakan pendapat. Hasil yang diperoleh adalah bahwa terdapat sebanyak 85 siswa pada umumnya kurang aktif dalam mengemukakan pendapatnya.

Hakikat keaktifan mengemukakan pendapat adalah keikut sertaan seseorang dalam aktivitas tertentu, misal proses pembelajaran, yang melibatkan kemampuan emosional dan menekankan kreativitas seseorang tersebut meningkatkan kemampuan minimalnya, serta kreatif, serta mampu menguasai konsep-konsep menurut Elza Firanda Riswani \& Ani Widayati (2012: 7). Dalam proses pembelajaran di sekolah, keaktifan mengemukakan pendapat merupakan kemampuan yang harus dimiliki semua siswa yang melibatkan unsur emosi dan bersifat efektif. Keterampilan mengemukakan pendapat didukung oleh kemampuan berargumentasi dan berbicara, yang tujuannya menyampaikan dan da;lam situasi tertentu mempertahankan ide dan gagasannya kepada orang lain. Seseorang tidak atau kurang memiliki keterampilan berbicara tentu akan mengalami kesulitan dalam menyampaikan gagasannya kepada orang lain.

Kenyataan di atas merupakan gambaran bahwa pada dasarnya sebagian besar siswa kelas VII SMP Negeri 1 Takeran Kabapaten Magetan adalah bermasalah dalam keaktifan 
mengemukakan pendapat. Alhasil kenyataan itu tidak menutup kemungkinan akan dapat menghambat perkembangan dan pencapaian tujuan pendidikan. Oleh sebab itu perlu segera dicarikan solusi. Salah satu solusi yang diyakini peneliti dapat meningkatkan keaktifan siswa dalam mengemukakan pendapat adalah diberi bimbingan pribadi dengan teknik reinforcement. Implementasi teknik reinforcement merupakan suatu metode pengubahan tingkah laku yang diberikan melalui penguatan-penguatan yang didefinisikan sebagai suatu konsekuensi yang memperkuat perilaku. Melalui pemberian treatment dengan model penguat akan terjadi perubahan yang positif pada diri siswa, sebagai akibat dari pemberian penguat setelah individu melakukan aktivitas yang bermanfaat bagi dirinya sendiri.

Agus Mulyadi (2004: 19) berpendapat bahwa pada dasarnya bimbingan pribadi adalah pemberian bantuan dari seorang konselor kepada individu dalam menemukan dan memahami, serta mengembangkan pribadinya secara optimal. Diperkuat pendapat dari Zainal Aqib (2012: 72) yang menyatakan bahwa bimbingan pribadi (personal guidance) adalah bantuan kepada individu yang bertujuan untuk memenuhi kebutuhan individu, hingga yang bersangkutan memiliki sarana objektif yang cukup di dalam kehidupan individu.

Hakikat teknik reinforcement menurut Saidiman (dalam Hamzah B. Uno, 2006: 168) cara atau model pemberian penguatan dari guru dalam merespons secara positif suatu tingkah laku tertentu siswa yang memungkinkan tingkah laku tersebut timbul kembali. Jeanne Ellis Ormrod (2008: 433) berpendapat bahwa teknik penguat (reinforcer) adalah setiap konsekuensi yang meningkatkan frekuensi perilaku tertentu, terlepas dari apakah orang-orang menganggap konsekuensi itu menyenangkan atau tidak.

Jenis metode reinforcement yang diterapkan dalam penelitian ini adalah penguatan positif (positive reinforcement), yang merupakan konsekuensi yang menghasilkan peningkatan perilaku melalui kehadiran (alih-alih penghilangan) sebuah stimulus (Jeanne Ellis Ormrod (2008: 434-435). Melalui tekhnik reiformcement dengan memberi peguatan positif diharapkan mampu mengubah perilaku siswa dari sebelumnya, dan hal ini membutuhkan strategi khusus.

Menurut Jeanne Ellis Ormrod (2009: 440-446) strategi memberikan reinforcement antara lain dapat ditempuh dengan kerja sama dengan guru, yakni sebagai berikut: 
(a) Mentukan perilaku yang diinginkan di awal pelajaran. Untuk memberikan reinforcement kepada siswa hendaknya ditentukan dulu perilaku apa yang akan ditingkatkan, contohnya adalah keaktifan mngemukakan pendapat.

(b) Identifikasikan konsekuensi-konsekuensi yang benar-benar memberikan penguatan bagi masing-masing siswa. Cara yang dilakukan adalah dengan mengamati perilakuperilaku siswa, sembari mencermati konsekuensi-konsekuensi yang tampaknya mereka hargai. Dan cara lainnya lagi adalah menarik kesimpulan dari apa yang dikatakan siswa.

(c) Gunakan penguat-penguat ekstrinsik hanya ketika perilaku yang diinginkan tidak akan terjadi tanpa penguat-penguat tersebut. Tidak mungkin dan juga tidak perlu memberikan penguatan pada setiap kelakuan baik. Lebih lanjut, banyak memberikan penguatan ekstrinsik tidak efektif ketika digunakan secara berulang kali.

(d) Buatlah kontingensi respons konsekuensi eksplisit.

Kontingensi respons ini melalui sebuah kontrak kontingensi (contingency contact) yaitu persetujuan formal antara guru dan siswa yang mengidentifikasi perilakuperilaku yang akan ditampilkan siswa dan penguat-penguat yang akan mengikutinya.

(e) Jika memberikan penguatan di depan umum, pastikan semua siswa mempunyai kesempatan untuk mendapatkannya. Sebagai usaha memperbaiki perilaku siswa di dalam kelas, kadang kita mengabaikan siswa lain yang sama-sama layak mendapat penguatan di dalam kelas tersebut. Agar tidak timbul kecemburuan sosial diharapkan guru mampu menempatkan diri dalam situasi yang seperti ini.

(f) Ketika berusaha mendorong perilaku yang sama pada sekelompok siswa, maka pertimbangkan menggunakan kontingensi kelompok. Bagi guru (konselor) yang ingin memberikan penguatan pada siswa dengan bentuk perilaku yang relatif sama. Maka guru lebih baik menggunakan penguatan melalui kelompoknya bukan pada siswanya. guru harus memastikan bahwa dalam kelompok tersebut semua siswa memberikan respon yang diinginkan.

(g) Jalankan penguatan secara konsisten sampai perilaku yang diinginkan terjadi sebagaimana diharapkan. Pemberian reinforcement yang konsisten akan sangat membantu guru untuk mencapai respons yang diinginkan. Penguatan paling penting ketika siswa pertama kali mempelajari perilaku baru, secara khusus perilaku yang tidak mudah dikuasai. 
(h) Ketika suatu perilaku sudah terbentuk dengan baik, hentikan siswa dari penguatan ekstrinsik, tetapi secara perlahan-lahan. Ketika suatu perilaku yang diberikan meningkat, guru perlu mencoba untuk mengurangi penguatan yang diberikan. Jadi pada akhirnya siswa akan mampu mempertahankan perilaku tersebut tanpa adanya penguatan.

(i) Monitor kemajuan siswa. Membandingkan frekuensi respons sebelum dan setelah diberikan penguatan, guru dan konselor dapat menentukan apakah prosedur penguatan yang diberikan benar-benar membawa perubahan perilaku atau tidak.

Prosedur yang dikembangkan dalam memberi pengukuhan positif agar diperoleh perubahan perilaku seseorang, mengacu pendapat Martin dan Pear (dalam Edi Purwanta, 2012: 35-36) yang menyatakan bahwa untuk meningkatkan terjadinya perilaku tertentu, diperlukan adanya prinsip-prinsip dalam pengukuhan positif, yaitu: (1) menyeleksi perilaku yang akan ditingkatkan, (b) perilaku yang diseleksi seharusnya perilaku yang khusus, misalnya "tersenyum" dari pada perilaku yang umum, misalnya "bersosialisasi".

(c) menyeleksi pengukuhan, dan (d) menggunakan pengukuhan positif.

Jadwal pemberian penguatan ditetapkan terdiri gabungan beberapa jadwal penguat yang dinyatakan oleh Robert E. Slavin (2008) sebagai berikut: Rasio Tetap (RF Fixed Ratio) dan Rasio Variabel (VR Variable Ratio). Jadwal Rasio Tetap (RF Fixed Ratio) merupakan salah satu jadwal penguatan yang lazim ialah jadwal rasio tetap, dimana suatu tindakan penguatan yang diberikan setelah perilaku dalam jumlah tetap. Jadwal Rasio Variabel (VR Variable Ratio) merupakan suatu jadwal rasio variabel penguatan adalah sesuatu dimana jumlah perilaku yang dibutuhkan untuk penguatan tidak dapat diperkirakan, walaupun dipastikan bahwa perilaku tersebut pada akhirnya akan dikuatkan.

Atas dasar kajian teori tersebut di atas maka dikemukakan hipotesis alternatif $\left(\mathrm{H}_{\mathrm{a}}\right)$, sebagai berikut: Ada peningkatan keaktifan mengemukakan pendapat setelah diberi bimbingan pribadi dengan teknik reinforcement pada siswa kelas VII SMP Negeri 1 Takeran Kabupaten Magetan tahun pelajaran 2013/2014.

\section{Metode Penelitian}

Metode penelitian menggunakan rancangan pra-eksperimental dengan desain onegroup pretest-posttest design. Pertimbangannya karena penggunaan desain one-group pretest-posttest design lebih sempurna karena menggunakan pretest dan posttest sehingga dapat diketahui sejauh mana perlakuan yang diberikan meningkat. 
Adapun desain penelitian dapat digambarkan dalam bagan sebagai berikut:

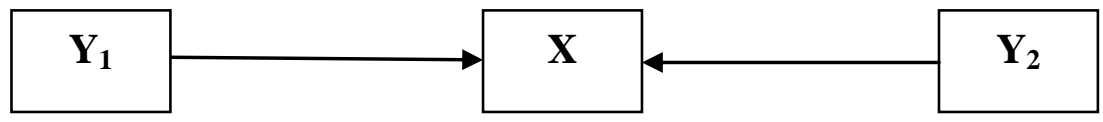

Bagan 1: One-Group Pretest-Posttest Design (Sugiyono, 2010: 74)

Keterangan:

$\mathbf{Y}_{1}$ : Variabel terikat pretest

$\mathbf{Y}_{2}$ : Variabel terikat posttest

$\mathbf{X}$ : Variabel bebas: bimbingan pribadi dengan menggunakan tekhnik reinforcement.

Penelitian dilaksanakan di SMP Negeri 1 Takeran, yang beralamat di di Jalan Sumbermulyo, Desa Jomblang, Kecamatan Takeran Kabupaten Magetan.

Populasi penelitian adalah siswa kelas VII SMP Negeri 1 Takeran Kabupaten Magetan tahun pelajaran 2013/2014, yang berjumlah 110 siswa. Sampel penelitian adalah sebanyak 20 dari 85 siswa yang memiliki kekurangan dalam keaktifan mengemukakan pendapat, yang ditetapkan dengan teknik random sampling.

Pengumpulan data menggunakan teknik observasi dan angket. Teknik observasi digunakan untuk memperoleh data tentang aktivitas mengemukakan pendapat dari responden. Teknik angket untuk mengungkap data efektifitas bimbingan pribadi dengan teknik reinforcement. Dalam penelitian ini disediakan satu seri angket, yang disebarkan dua kali, yaitu sebelum dan sesudah diberi treatment bimbingan pribadi dengan teknik reinforcement. Angket disusun dalam bentuk pilihan ganda, dengan empat alternatif jawaban yaitu a (selalu), b (sering), c (kadang-kadang, dan d (tidak pernah). Jumlah irtem angket yang disediakan adalah 20 butir. Analisi data menggunakan teknik statistik, dengan rumus bangun t-skor.

\section{Hasil Penelitian}

\section{Deskripsi Data}

a. Deskripsi data skor angket keaktifan mengemukakan pendapat sebelum diberi bimbingan pribadi dengan teknik reinforcement $(X)$. Dengan rentangan skor: 2080 , $\mathrm{N}$ sebanyak 20, diperoleh perhitungan sebagai berikut: mean $=39,5$, median $=$ 40 , modus $=34$, skor terendah $=33$, dan skor tertinggi adalah 50. Mengingat data skor angket keaktifan mengemukakan pendapat sebelum diberi bimbingan pribadi 
dengan teknik reinforcement akan dilaporkan dalam bentuk grafik histogram, maka perlu menghitung range (R) dan lebar kelas (i). Range (R) adalah selisih antara batas atas nyata skor tertinggi dengan batas bawah nyata skor terendah $(50,5-32,5)=18$. Ditentukan lebar kelas $(\mathrm{i})=3$, maka $\mathrm{R}$ dalam distribusi frekuensi bergolong: $18: 3-6$ (Lihat tabel 1).

Tabel 1. Distribusi Frekuensi Skor Angket Keaktifan Mengemukakan Pendapat Sebelum Diberi Bimbingan Pribadi Dengan Teknik Reinforcement

\begin{tabular}{|c|c|c|}
\hline $\begin{array}{c}\text { Interval Nilai } \\
(\mathrm{I})\end{array}$ & $\begin{array}{c}\text { Titik Tengah } \\
(\mathrm{Xi})\end{array}$ & $\begin{array}{c}\text { Frekuensi } \\
(\mathrm{f})\end{array}$ \\
\hline $33-35$ & 32 & 6 \\
\hline $36-38$ & 35 & 2 \\
\hline $39-41$ & 38 & 5 \\
\hline $42-44$ & 43 & 5 \\
\hline $45-47$ & 46 & 1 \\
\hline $48-50$ & 49 & 1 \\
\hline
\end{tabular}

Bentuk grafik histogram adalah sebagai berikut:

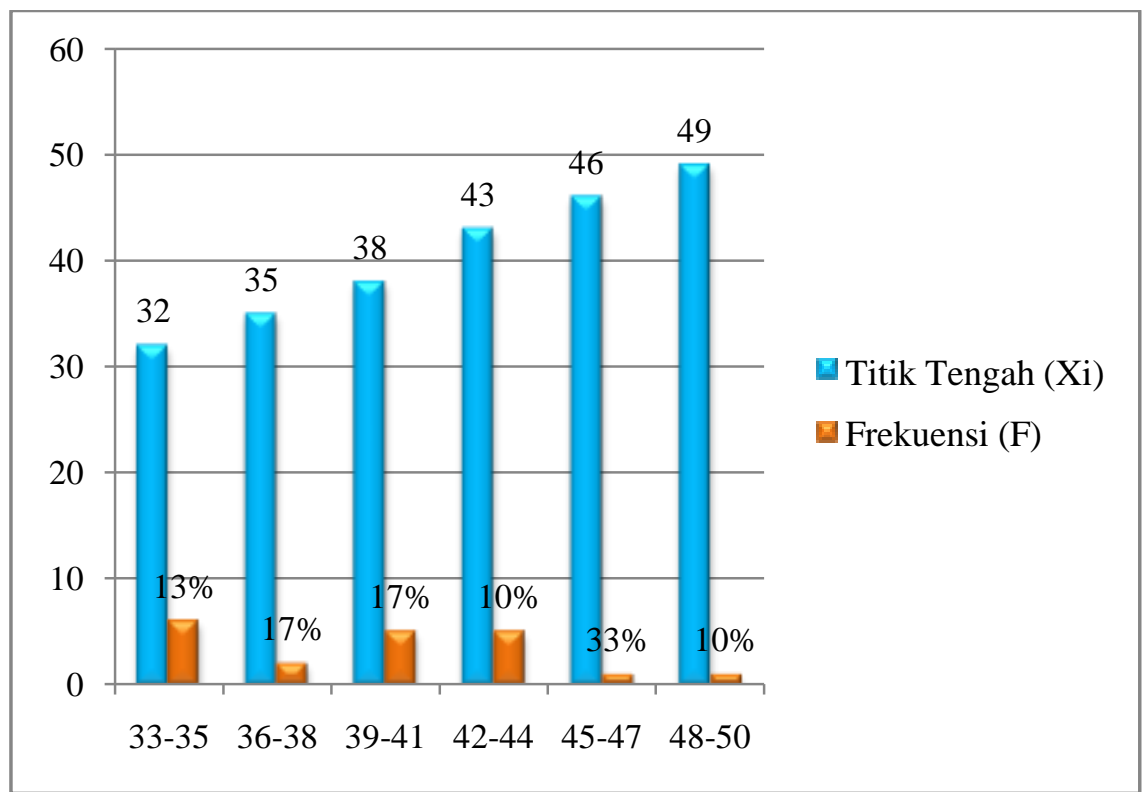

Grafik 1. Data Skor Keaktifan Mengemukakan Pendapat Sebelum Diberi Bimbingan Dengan Teknik Reinforcement.

b. Deskripsi data skor angket keaktifan mengemukakan pendapat setelah diberi bimbingan pribadi dengan teknik reinforcement $(Y)$. Dengan rentangan skor: 20- 
80 , $\mathrm{N}$ sebanyak 20 , diperoleh perhitungan sebagai berikut: mean $=55$, median $=$ 54,5 , modus $=52$, skor terendah $=47$, dan skor tertinggi adalah 64. Mengingat data skor angket keaktifan mengemukakan pendapat sebelum diberi bimbingan pribadi dengan teknik reinforcement akan dilaporkan dalam bentuk grafik histogram, maka perlu menghitung range (R) dan lebar kelas (i). Range (R) adalah selisih antara batas atas nyata skor tertinggi dengan batas bawah nyata skor terendah $(64,5-46,5)=18$. Ditentukan lebar kelas $(\mathrm{i})=3$, maka $\mathrm{R}$ dalam distribusi frekuensi bergolong: $18: 3-6$ (Lihat table 1).

Tabel 2. Distribusi Frekuensi Skor Angket Keaktifan Mengemukakan Pendapat Setelah Diberi Bimbingan Pribadi Dengan Teknik Reinforcement

\begin{tabular}{|c|c|c|}
\hline $\begin{array}{c}\text { Interval nilai } \\
(\mathrm{I})\end{array}$ & $\begin{array}{c}\text { Titik Tengah } \\
(\mathrm{Xi})\end{array}$ & $\begin{array}{c}\text { Frekuensi } \\
(\mathrm{f})\end{array}$ \\
\hline $47-49$ & 48 & 2 \\
\hline $50-52$ & 51 & 6 \\
\hline $53-55$ & 52 & 3 \\
\hline $56-58$ & 57 & 5 \\
\hline $59-61$ & 60 & 2 \\
\hline $62-64$ & 63 & 2 \\
\hline
\end{tabular}

Bentuk grafik histogram adalah sebagai bwerikut:

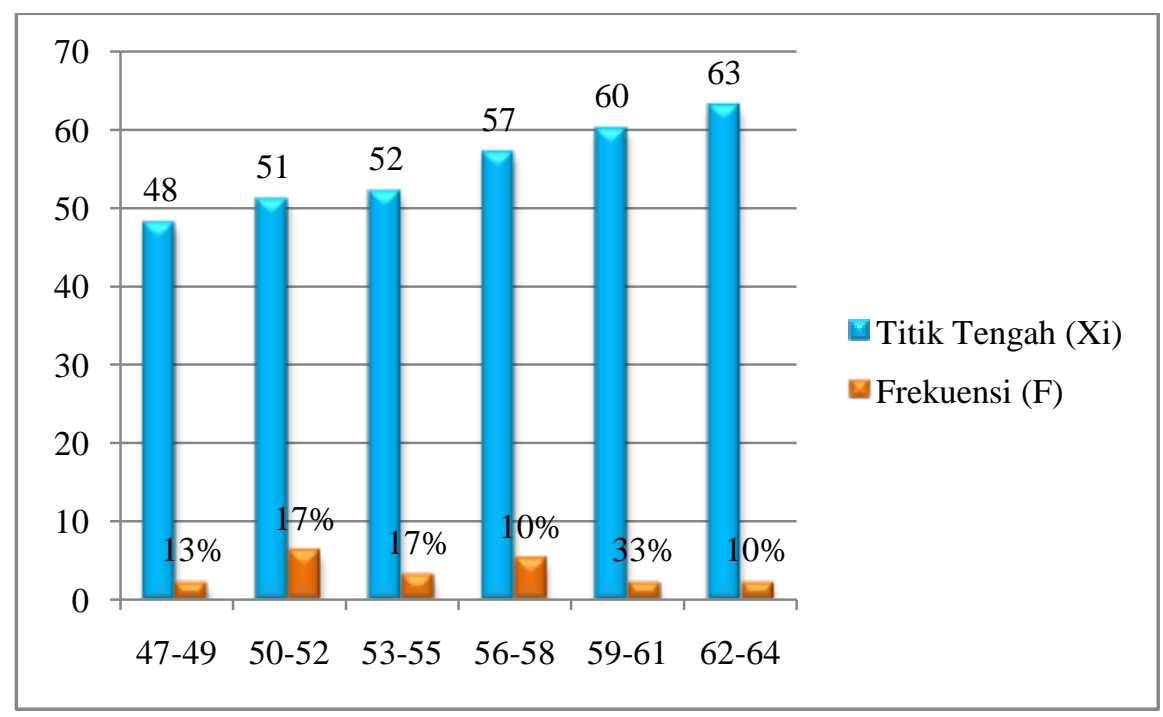

Grafik 2 Skor Angket Keaktifan Mengemukakan Pendapat Setelah diberi Bimbingan Pribadi dengan Teknik Reinforcement. 


\section{Hasil Analisis Data Penelitian}

Untuk keperluan analisis data membutuhkan tabel persiapan untuk menghitung perbedaan skor antara sebelum dan sesudah diberi bimbingan pribadi dengan teknik reinforcement. Berikut tabel yang dimaksud dalam pembahasan ini.

Tabel 3. Persiapan Menghitung Keaktifan Mengemukakan Pendapat Antara Sebelum dan Sesudah Diberi Bimbingan Pribadi Dengan Teknik Reinforcement

\begin{tabular}{|r|r|r|r|r|r|r|r|r|}
\hline $\begin{array}{l}\text { No } \\
\text { Urt }\end{array}$ & $\mathrm{X}_{1}$ & $\mathrm{X}_{2}$ & \multicolumn{1}{|c|}{$\sum \mathrm{d}$} & $\left(\mathrm{d}-\mathrm{M}_{\mathrm{d}}\right)$ & $\sum \mathrm{d}^{2}$ & $\left(\sum \mathrm{d}\right)^{2}$ & \multicolumn{1}{c|}{$\left(\sum \mathrm{d}\right)^{2}$} & $\left(\sum \mathrm{X}^{2} \mathrm{~d}\right)$ \\
\hline 01 & 40 & 53 & 13 & -156 & 245 & 169 & \multicolumn{1}{c|}{$\mathrm{N}$} & \\
\hline 02 & 47 & 52 & 5 & -20 & 245 & 25 & 1,25 & 23,75 \\
\hline 03 & 44 & 49 & 5 & -20 & 245 & 25 & 1,25 & 23,75 \\
\hline 04 & 42 & 54 & 12 & -132 & 245 & 144 & 7,20 & 136,80 \\
\hline 05 & 39 & 52 & 13 & -156 & 245 & 169 & 8,45 & 160,55 \\
\hline 06 & 42 & 61 & 19 & -342 & 245 & 361 & 18,05 & 342,95 \\
\hline 07 & 41 & 56 & 15 & -210 & 245 & 225 & 11,25 & 21375 \\
\hline 08 & 34 & 64 & 30 & -870 & 245 & 900 & 4.50 & 855,00 \\
\hline 09 & 42 & 58 & 16 & -240 & 245 & 256 & 12,8 & 243,20 \\
\hline 10 & 35 & 63 & 28 & -756 & 245 & 784 & 39,2 & 744,80 \\
\hline 11 & 34 & 51 & 17 & -272 & 245 & 289 & 14,45 & 274,55 \\
\hline 12 & 40 & 58 & 18 & -306 & 245 & 324 & 16,20 & 307,80 \\
\hline 13 & 33 & 51 & 18 & -306 & 245 & 324 & 16,20 & 307,80 \\
\hline 14 & 35 & 57 & 22 & -462 & 245 & 484 & 1,25 & 459,80 \\
\hline 15 & 43 & 59 & 16 & -240 & 245 & 256 & 24,20 & 243,20 \\
\hline 16 & 37 & 52 & 15 & -210 & 245 & 225 & 12,80 & 213,75 \\
\hline 17 & 41 & 51 & 10 & -90 & 245 & 100 & 11,25 & 95,00 \\
\hline 18 & 38 & 47 & 9 & -72 & 245 & 81 & 5,00 & 76,95 \\
\hline 19 & 34 & 55 & 21 & -420 & 245 & 441 & 4,05 & 418,95 \\
\hline 20 & 50 & 57 & 7 & -42 & 245 & 49 & 2,45 & 46,55 \\
\hline$\sum$ & & & 245 & & & & & 3447,55 \\
\hline & & & & & & & & \\
\hline
\end{tabular}

Berdasarkan taberl 3 di atas maka dapat digunakan untuk menghitung sebagai berikut:

1. $\mathrm{Md}=\frac{\left(\sum \mathrm{d}\right)}{\mathrm{N}}=245 / 20=12,25$

$\mathrm{Md}$

12,25

12,25

$\mathrm{t}=\mathrm{-}\left(\sum \mathrm{X}^{2} \mathrm{~d}\right): \mathrm{N}(\mathrm{N}-1) \quad \sqrt{ }(3447,55): 20(20-1) \quad \sqrt{ } 8,8399$

$$
=\frac{12,25}{2,973}=4,171
$$


3. Menghitung d.b dan menentukan taraf kepercayaan

d.b $=\mathrm{N}_{1}+\mathrm{N}_{2}=20+20-2=40-2=38$, dengan d.b 38 maka taraf kepercayaan $5 \%=1,699$. Jadi t-hitung $>$ t-tabel/TS=5\%. Jadi hipotesis $\left(\mathrm{H}_{\mathrm{a}}\right)$ harus diterima atas dasar taraf kepercayaan 5\%. Artinya ada peningkatan keaktifan mengemukakan pendapat setelah diberi bimbingan pribadi dengan teknik reinforcement.

\section{Simpulan Penelitian}

Bertolak dari hasil analisis data maka dapat disimpulkan bahwa: ada peningkatan keaktifan mengemukakan pendapat setelah diberi bimbingan pribadi dengan teknik reinforcement pada siswa kelas VII SMP Negeri 1 Takeran Kabupaten Magetan tahun pelajaran 2013/2014. Saran yang dikemukakan adalah pihak sekolah untuk senantiasa memberikan kesempatan siswa mengemukakan pendapatnya melalui proses pembelajaran. Pihak konselor sekolah sebaiknya menyusun layanan bimbingan pribadi dengan melibatkan peran siswa dalam berpendapat, dan menghargai perbedaan pendapat.

\section{DAFTAR PUSTAKA}


Abu Ahmadi. 2003. Psikologi Umum. Jakarta: Rineka Cipta.

Agus Mulyadi. 2004. Dasar-dasar Bimbingan dan Konseling. Jakarta: Depdiknas. Dirjen

Pendidikan Dasar dan Menengah Direktorat Tenaga Kependidikan.

Baharudin dan Esa Nur Wahyuni. 2007. Teori Belajar dan Pembelajaran. Yogyakarta: ArRuz Media.

Burhan Bungin. 2005. Metode Penelitian Kuantitatif. Jakarta: Pustaka Pelajar.

Edi Purwanto. 2012. Modifikasi Perilaku. Yogyakarta: Pustakan Pelajar.

Elfi Mu'awanah dan Rifa Hidayah. 2009. Bimbingan dan Konseling Islami di Sekolah Dasar. Jakarta: Bumi Aksara.

Elza Firanda Riswani \& Ani Widayati. 2012. Model Aktive Learning Dengan Teknik Leraning Starts With A Question Dalam Peningkatan Keaktivitan Peserta Didik Dalam Mata Pelajaran Akuntansi Kelas XI Ilmu Sosial 1 SMA Negeri 7 Yogyakarta: Jurnal Pendidikan Akuntansi Indonesia, Vol.X (http://www, Universitas Negeri Yogyakarta.ac.id, Diunduh 28 Maret 2013.

Eti Nurhayati. 2011. Bimbingan Konseling dan Psikoterapi Inovatif. Yogyakarta: Pustaka Pelajar.

Ormrod, Jeanne Ellis. Psikologi Pendidikan. Jakarta: Erlangga.

Slavin, E. Robert. 2008. Psikologi Pendidikan Teori dan Praktek. Jakarta: PT Indeks.

Sugiyono. 2010. Metode Penelitian Pendiikan Pendekatan Luantiotatof, Kualitatif, dan $R \& D$. Bandung: Alfabeta.

Sumadi Suryabrata, 2012. Psikologi Pendidikan. Jakarta: Rawali Pers.

Syamsu Yusuf dan Achmad Juntika Nurihsan. Landasan Bimbingan dan Konseling. Bandung: Remaja Rosdakarya.

Vitalis Djarot S. 2012. Statistik Inferensial. Madiun: IKIP PGRI Madiun.

Zainal Aqib. 2012. Ikhtisar Bimbingan dan Konseling di Sekolah. Bandung: Yrama Widya. 